\title{
BUSINESS EDUCATION EXCELLENCE
}

\begin{abstract}
Liene Resele ${ }^{1}$, Dr.sc.administr.; Dace Stefenberga2, Master of Business Administration; Agnese Jekabsone ${ }^{3}$, Master of Business Administration; Elina Erkske ${ }^{4}$, and Madara Krisjane ${ }^{5}$
\end{abstract}

Abstract. Universities prepare professionals who will guide and influence organizations in the future, so the issue of qualitative, excellent business education is and will continue to be relevant. How to identify universities that provide qualitative business education is a topical issue for potential students, parents and universities themselves.

Aim of this research was to explore what is understood in the scientific literature by "business education excellence and quality", by which methods they are evaluated and raised and to develop recommendations for practically applicable methods in a university.

It may be concluded that in the studies on the quality and/or excellence of higher education, the definitions of these terms are often not provided or are different and vary widely. The evaluation methods used are also different. Evaluating the quality and/or excellence of higher education is a difficult task and often impossible because it requires a standard to compare. The quality and/or excellence of higher education can be judged by the use of indicators, such as the number of companies established by graduates, profits of start-ups, the number of jobs created, the amount of taxes paid. In order to produce qualitative results, it is important to provide high quality inputs - program, academic staff, students, material resources, and environment. University ratings and quality certificates shall not be used as key tools for assessing the quality/excellence of higher education. Universities are facing new challenges and their success will be greatly influenced by their ability to change, to be fast, creative and cooperative.

Key words: business education excellence, quality.

JEL code: I23.

\section{Introduction}

The concept of "excellence" is mentioned in the development strategies of universities, both in the mission and in the vision. Often, the quality of studies is mentioned in different types of meetings, whether in universities or outside, or that the quality of studies is falling, not always using these terms correctly. How to identify universities that provide qualitative business education is a topical issue for potential students, parents and universities themselves. As Dennis (Dennis et al., 2016) notes, quality and university reputation are the two factors that most influence student choice. Demand for qualified graduates will only increase with the global economy expanding into new markets. According with Kolb (Kolb et al., 2017), universities are the main source of management education and provide a link between knowledge creation and knowledge transfer in business and society at large. Universities prepare professionals who will guide and influence organizations in the future, so the issue of qualitative, excellent business education is and will continue to be relevant.

One of the key issues in this study was whether university ratings and quality certificates can be used as main quality assessment tools. Aim of this research was to explore what is understood in the scientific literature by the terms "business education excellence”, "business education quality", by which methods they are evaluated and raised and to develop recommendations for practically applicable methods in a university. The tasks of the research were to analyse scientific literature, to select and study the most often used university ratings and quality certificates, to conduct a survey of graduates of Faculty of Economics and Management of Ventspils University of Applied Sciences, and to provide recommendations, including practically applicable methods. Methods applied in this

\footnotetext{
${ }^{1}$ Liene.resele@venta.Iv; Ventspils University of Applied Sciences, Latvia

2 Dace.stefenberga@venta.Iv; Ventspils University of Applied Sciences, Latvia

3 Agnese.jekabsone@venta.Iv; Ventspils University of Applied Sciences, Latvia

4 m7_klauze_e@venta.Iv; Ventspils University of Applied Sciences, Latvia

5 Madara.krisjane@venta.Iv; Ventspils University of Applied Sciences, Latvia
} 
research - monographic or descriptive method, comparative analysis, constructive logic, analysis and synthesis, and survey. Information sources are scientific articles, research about the excellence in higher education, internet sources.

\section{Quality and excellence of business education}

The term "excellence" is traditionally associated with a difference, with a quality that is unusually good and goes beyond certain standards (Grifoll, 2016). Malmedy (ENQA, 2014) indicates:

- excellence is closely linked to assessment;

- something is always recognized as outstanding, not in itself, but in relation to a system that contains criteria;

- the judgment of excellence depends on the criteria that have been chosen;

- selected criteria develop in time and space, they are not arbitrary;

- thus, the assessment of excellence depends on the person or society providing it;

- evaluation, judgment given may be emotionally distorted due to personal interests, ignorance of certain facts, bias, non-compliance.

Defining higher education excellence is not an easy task. Often, in researches on the quality, excellence of higher education definitions of these concepts are not provided. At the same time, it is possible to find different definitions of quality, excellence in other studies because its universal meaning is linked to the social and cultural, as well as the political and economic environment that is changing in time and space. As noted by Grifoll (Grifoll, 2016), higher education is an activity (service) that is both public and private. Its private aspect is that graduates are looking for better jobs and better wages in a competitive labour market. Its public dimension is determined by the fact that various positive factors are being created that affect the external environment, such as the possibility of obtaining expertise in areas that contribute to the well-being of society as a whole. Hence, excellence in higher education depends on the party involved - individuals / organizations that define this term (students, families, society, employers, others) and its motivation to do so.

According to Grifoll (Grifoll, 2016), excellence in higher education is:

- a combination of certain inputs (program quality, quality of lecturers, quality of students, etc.) and outputs;

- a culture of use of inputs and cyclical progress towards better results;

- list of expected goals.

When discussing the quality of higher education, it is needed to understand clearly what is being discussed - the study program, its implementation (study process) or its results. The quality, excellence of higher education firstly can be evaluated by its outputs, which are evidenced by indicators such as the number of companies established by graduates, profits of established companies, the number of jobs created, the amount of taxes paid. In order to produce qualitative results, it is important to provide a qualitative study program and its implementation, where inputs are important. The responsibility of the university is to ensure the internal quality so that the student can produce external quality - results (Figure 1 ). 


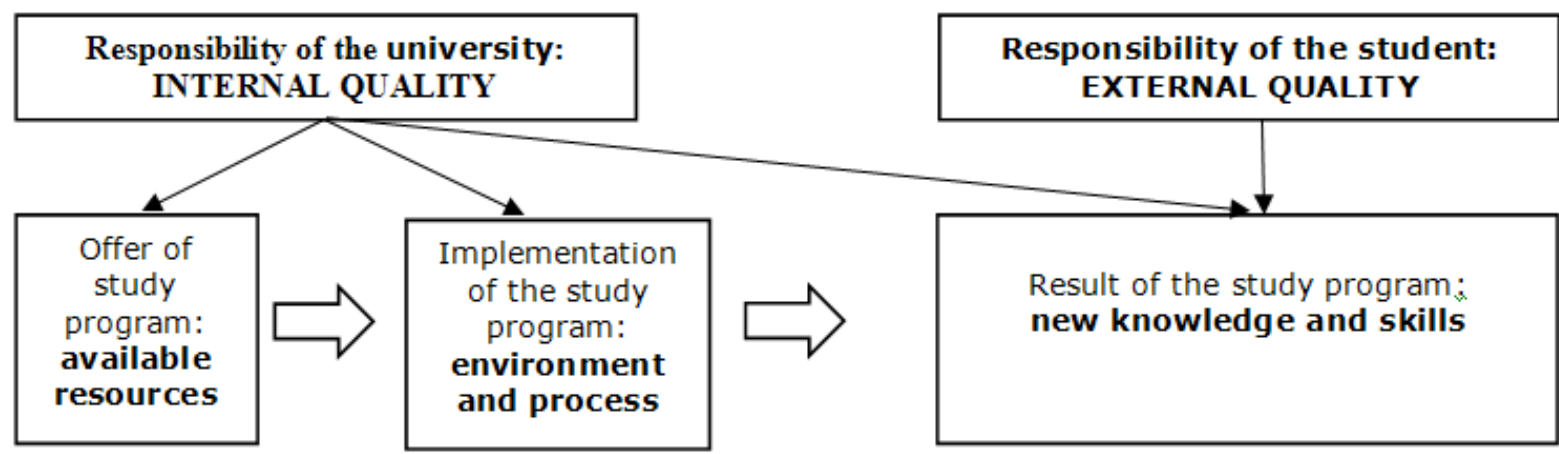

Source: created by authors, based on Bandevica, Ligotne, 2014

Fig. 1. Components of quality of higher education

In recent years, the processes of learning and recognition of qualifications have changed in the world, gradually shifting to a competence approach and higher education based on knowledge and experience. The World Economic Forum concludes (Schwab, 2016) that we are on the eve of the Fourth Industrial Revolution, the main challenges of which are how mankind will react in the face of changes in education and labour qualification caused by artificial intelligence. The question is what will be the jobs that artificial intelligence will do in the coming decades. Therefore, innovative and unique ideas are the only source of business excellence and, accordingly, the learning-by-doing approach will enhance the excellence of the business education process.

\section{Evaluation of Quality and excellence of business education}

Tavares (ENQA, 2014) mentions that world university ratings are considered key indicators of excellence, reflecting power and political interests, and using the traditional understanding of higher education excellence, emphasizing research rather than teaching and learning. Therefore, one of the key issues in this study was whether university ratings and quality certificates can be used as main quality assessment tools.

\section{University ratings}

The world's most well-known university ratings and most often mentioned in the Latvian media are: the Times Higher Education World University Rankings and QS World University Rankings. Thus, these two ratings, and their methodology is described in more detail in this research. Every rating has its own methodology for data selection, compilation and comparison of universities.

\section{The Times Higher Education World University Rankings}

The information below is taken from the the World University Rankings website.

The published 2019 rating includes over 1250 universities worldwide. This rank includes the world's best universities by analysing:

- teaching (the learning environment) - $30 \%$ (reputation survey: $15 \%$, staff-to-student ratio: $4.5 \%$, doctorate-to-bachelor's ration: $2.25 \%$, doctorates-awarded-to-academic-staff ratio: $6 \%$, institutional income: 2.25$)$;

- research (volume, income and reputation) - $30 \%$ (reputation survey: $18 \%$, research income: $6 \%$, research productivity: $6 \%$ );

- citations (research influence) $-30 \%$;

- international outlook (staff, students, research) - $7.5 \%$ (proportion of international students: $2.5 \%$, proportion of international staff: $2.5 \%$, international collaboration: $2.5 \%$ );

- industry income (knowledge transfer) - $2.5 \%$.

Rating data is audited by international company PricewaterhouseCoopers. 
It is possible to select universities according to the study fields they offer. Analysing universities offering business and management study programs, the top 10 universities this year are Stanford University (USA), Massachusetts Institute of Technology (USA), Harvard University (USA), Yale University (USA), Imperial College London (UK), University of Chicago (USA), ETH Zurich (Switzerland), John Hopkins University (USA), University of Pennsylvania (USA) and UCL (UK).

Two universities from Latvia have been included in this rating: Riga Technical University (RTU) and the University of Latvia. Both are ranked 801 to 1000 in the rating.

\section{QS World University Rankings}

The information below is based on the rating, methodology, aggregated results and data published on the QS World University Rankings website.

This rank includes 1000 of the world's best universities from 85 different countries. The rating is based on the following criteria:

- academic reputation - $40 \%$;

- reputation of employers - $10 \%$;

- faculty/student ratio - $20 \%$;

- citations per faculty - $20 \%$;

- international faculty ratio - $5 \%$;

- international student ratio - $5 \%$.

Also in this rating it is possible to select and analyse universities according to the fields of study programs they offer. The rating includes 1423 universities offering study programs in business and management.

Three universities - Riga Technical University, University of Latvia and Riga Stradins University are included in this rating from Latvia. RTU ranked the highest among Latvian universities - 751st 800th place. Other two universities are ranked 801 to 1,000 .

International ratings can be one of the universities' benchmarking tools, but evaluation of university excellence should not be based on only those ratings, as not all universities are included in the ratings, and Figures can be interpreted differently, so the data does not always reflect the true situation and real university excellence.

\section{Certificates and accreditations}

International certification and accreditation is one of the ways to evaluate the quality of education. The three best-known certificates and accreditations that provide a "seal" of excellence for universities in the world education system are AACSB, EQUIS and AMBA.

\section{AACSB}

The Association to Advance Collegiate Schools of Business - AACSB - connects educators, students, and business to achieve a common goal: to create the next generation of great leaders. Since 1916, AACSB provides quality assurance, business education intelligence, and professional development services to over 1,600 member organizations and more than 800 accredited universities worldwide.

\section{EQUIS}

EQUIS is institutional accreditation system for business and management universities. It is acknowledged worldwide by potential students, faculty, employers, corporate clients and the media, often being a pre-requisite for entry to rankings. EQUIS accreditation ensures a rigorous quality control, benchmarking university against international standards in terms of governance, 
programmes, students, faculty, research, internationalisation, ethics, responsibility and sustainability, as well as corporate engagement.

\section{AMBA}

AMBA - the Association of MBAs is the impartial authority on postgraduate management education and is committed to raising its profile and quality standards internationally for the benefit of business universities, students and alumni and employers. AMBA established that vision in 1967 and it is as relevant today as it was over 50 years ago. Accreditation service of AMBA is the global standard for all MBA, DBA and Master's degrees, currently accrediting programmes from the top $2 \%$ of business universities in over 70 countries.

In business education, the triple certification: AACCSB, EQUIS, AMBA, serves as a "gold standard" (Figure 2) - if the organization has all three certificates, then such a university has internationally recognizable advantages over other universities.

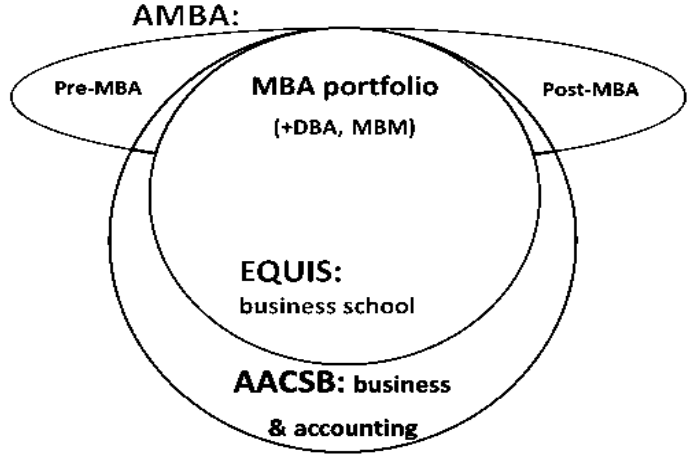

Source: https://www.mbaworld.com/about-us

Fig. 2. Relationships between business education certification organizations

\section{Alumni database}

In order to evaluate the quality of business education provided by Ventspils University of Applied Sciences, the database of graduates of the Faculty of Economics and Management was developed and the number of graduates working in the sector and the number of graduates having established their company was determined.

Since 2001, 1404 students have graduated from faculty of Economics and Management of Ventspils University of Applied Sciences (Table 1). 991 graduate was interviewed via email, online social network www.facebook.com, and phone calls, asking for a work place, occupation, telephone number and e-mail address, and whether the graduate has established his or her business. 391 graduate responded, representing 28 \% of all graduates. 413 graduates were not able to address because there was No telephone number or e-mail, and the person could not be found or identified on the online social networks www.facebook.com and www.linkedin.com. 
Results of graduates' survey of the Faculty of Economics and Management of Ventspils University of Applied Sciences

\begin{tabular}{|l|c|c|c|c|c|c|c|}
\hline Year & $\begin{array}{c}\text { Study } \\
\text { Program }\end{array}$ & $\begin{array}{c}\text { Number } \\
\text { of } \\
\text { graduates }\end{array}$ & $\begin{array}{c}\text { Graduates } \\
\text { without } \\
\text { contact } \\
\text { information }\end{array}$ & $\begin{array}{c}\text { Graduates } \\
\text { who have } \\
\text { not } \\
\text { provided } \\
\text { information }\end{array}$ & $\begin{array}{c}\text { Graduates } \\
\text { who } \\
\text { provided } \\
\text { information }\end{array}$ & $\begin{array}{c}\text { Graduates } \\
\text { who have } \\
\text { founded } \\
\text { the } \\
\text { company }\end{array}$ & $\begin{array}{c}\text { Graduates } \\
\text { working } \\
\text { in the } \\
\text { industry* }\end{array}$ \\
\hline $\begin{array}{l}\mathbf{2 0 0 1 -} \\
\mathbf{2 0 1 8}\end{array}$ & Bachelor & 1064 & 334 & 463 & 267 & 59 & 97 \\
\hline $\begin{array}{l}\mathbf{2 0 0 3 -} \\
\mathbf{2 0 1 8}\end{array}$ & Master & 340 & 79 & 137 & 124 & 30 & 55 \\
\hline Total & & 1404 & 413 & 600 & 391 & 89 & 152 \\
\hline
\end{tabular}

* Manages a company or department, is a director or specialty manager

Source: author's calculations based on survey

Summarizing the results of both the bachelor and master program graduates' database, it can be concluded that graduates of Ventspils University of Applied Sciences are competitive in the labour market - on average $23 \%$ of graduates (who provided information) have established their own companies and on average $39 \%$ of graduates (who provided information) have taken managerial positions, are heads of company or department. It has been observed that more companies have been founded by graduates who have graduated from Ventspils University of Applied Sciences earlier, which is likely to be related to accumulated work experience. In contrast, the number of graduates working in the industry is quite similar in all years, which means that younger graduates have also been able to succeed in leading positions.

\section{Increasing the Quality and excellence of business education}

Kaplan (Kaplan, 2018) recommends using a resource-based view to better identify the valuecreating aspects of business education and to better understand the dimensions that universities will have to adapt. According to the resource-based approach, a sustainable competitive advantage is determined by the organisation's strategic resources, which must be valuable (enabling strategies to improve efficiency), rare (not easily accessible to competitors), non-deployable (non-interchangeable with others) and completely immeasurable. In the case of business universities, Kaplan (Kaplan, 2018) mentions three resource groups - students and alumni, equipment and services, lecturers and researchers, and four major challenges facing business universities - the transition from the ivory tower to the Twittersphere, the transition from auditorium to anti-cafe, a move from stakeholders to shareholders, a transition from knowledge to know-how (Table 2). 
Resources and challenges of universities

\begin{tabular}{|c|c|c|c|c|}
\hline & \multirow[b]{2}{*}{ Challenges } & \multicolumn{3}{|c|}{ Resources } \\
\hline & & $\begin{array}{l}\text { Students and } \\
\text { alumni }\end{array}$ & $\begin{array}{l}\text { Equipment and } \\
\text { services }\end{array}$ & $\begin{array}{l}\text { Lecturers and } \\
\text { researchers }\end{array}$ \\
\hline \multirow{4}{*}{ 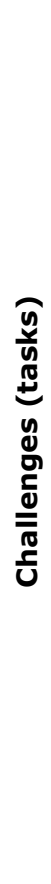 } & $\begin{array}{l}\text { From tower to } \\
\text { Twittersphere }\end{array}$ & $\begin{array}{l}\text { Selection takes ability } \\
\text { to serve as brand } \\
\text { ambassadors and } \\
\text { value in rankings and } \\
\text { accreditations into } \\
\text { account }\end{array}$ & $\begin{array}{c}\text { Importance of } \\
\text { branding and } \\
\text { communication, } \\
\text { architecture, and } \\
\text { having the right image }\end{array}$ & $\begin{array}{c}\text { Research topics chosen, } \\
\text { in part, for their PR } \\
\text { potential; higher } \\
\text { importance of star } \\
\text { teachers and } \\
\text { researchers }\end{array}$ \\
\hline & $\begin{array}{c}\text { From auditorium to } \\
\text { anti-cafe }\end{array}$ & $\begin{array}{l}\text { Evolution from } \\
\text { passive consumers of } \\
\text { knowledge to active } \\
\text { co-producers of } \\
\text { course content }\end{array}$ & $\begin{array}{l}\text { Need for flexible } \\
\text { layouts to enable } \\
\text { group work and } \\
\text { interactivity; } \\
\text { importance of online } \\
\text { courses }\end{array}$ & $\begin{array}{c}\text { Knowledge transmission } \\
\text { moved to online sphere; } \\
\text { classroom time used for } \\
\text { highly interactive } \\
\text { teaching }\end{array}$ \\
\hline & $\begin{array}{l}\text { From stakeholders } \\
\text { to shareholders }\end{array}$ & $\begin{array}{l}\text { Shift from students to } \\
\text { customers and future } \\
\text { donors, resulting in } \\
\text { higher } \\
\text { customer/student } \\
\text { centricity }\end{array}$ & $\begin{array}{l}\text { Shift from bureaucracy } \\
\text { and administration to } \\
\text { becoming a concierge- } \\
\text { like service provider }\end{array}$ & $\begin{array}{l}\text { Faculty becomes one of } \\
\text { several stakeholder } \\
\text { groups to be managed, } \\
\text { creating need for } \\
\text { compromise }\end{array}$ \\
\hline & $\begin{array}{c}\text { From knowledge to } \\
\text { know-how }\end{array}$ & $\begin{array}{l}\text { Selection based on } \\
\text { soft skills in addition } \\
\text { to intellectual } \\
\text { achievements } \\
\text { (grades) }\end{array}$ & $\begin{array}{c}\text { Importance of expert } \\
\text { career service that } \\
\text { provides professional } \\
\text { advice and job off ers } \\
\text { to students based on } \\
\text { skill s and personality } \\
\text { traits }\end{array}$ & $\begin{array}{l}\text { Evolution of faculty from } \\
\text { knowledge professionals } \\
\text { to coaches and } \\
\text { facilitators in a } \\
\text { transversal and } \\
\text { interdisciplinary setting }\end{array}$ \\
\hline
\end{tabular}

Source: Kaplan, 2018

\section{Conclusions}

1) In the studies on the quality and / or excellence of higher education, the definitions of these terms are often not provided or are different and vary widely, due to factors such as time, space and the interested party. The valuation methods used are also different.

2) Evaluating the quality and / or excellence of higher education is a difficult task and often impossible because it requires a standard to compare.

3) The quality and / or excellence of higher education can be judged by the use of indicators, such as the number of companies established by graduates, profits of start-ups, the number of jobs created, the amount of taxes paid. In order to produce qualitative results, it is important to provide high quality inputs - program, academic staff, students, material resources, and environment.

4) University ratings and quality certificates shall not be used as key tools for assessing the quality and / or excellence of higher education.

5) Universities are facing new challenges and their success will be greatly influenced by their ability to change, to be faster and more creative in decision-making and in action, to be able to work with key stakeholders and to create a more dynamic, involved, motivated academic and general staff, students, graduates, a community of different partners, where each of the parties involved will be ready to act as brand ambassadors and promote quality.

\section{Recommendations}

1) To make changes to the governance structure of university and promote an entrepreneurial mindset that enables faster decision-making and action.

2) To develop and use an effective, flexible and change-oriented quality assessment system. 
3) To create a strategy and action plan for relationship management with graduates.

4) To establish a career guidance centre providing support to students on the one hand and providing companies with access to the best students and academic staff (on a pay-per-view basis) on the other.

5) To prepare regularly a scientifically popular article for the media (about once a quarter).

6) To evaluate the possibility of the university to participate in one of the ratings, fulfil the necessary conditions and provide the necessary data to compare the results with other similar universities, as well as to evaluate the areas and criteria for improvement.

7) Regularly (annually) supplement and update the database of graduates.

8) To create a series of guest lectures, where graduates are invited to encourage and cheer students, to tell students their career success stories.

\section{Bibliography}

1. Bandevica L., Ligotne A. Higher Education Study Programme Quality Assessment // Regional Formation and Development Studies. - 2014. - No. 2. - pp. 6-18.

2. Dennis C. et al. The Role of Brand Attachment Strength in Higher Education // Journal of Business Research. - 2016. - Vol. 69. - pp. 3049-3057.

3. ENQA. The Concept of Excellence in Higher Education. - Brussels, 2014. pp. 1-45.

4. Grifoll J. External Quality Assurance Agencies and Excellence in Higher Education // Educacion Medica. 2016. - Vol. 17, No. 3. - pp. 94-96.

5. Kaplan A. A School is „A Building that has Four Walls ... with Tomorrow Inside”: Toward the Reinvention of the Business School // Business Horizons. - 2018. - pp. 599-608.

6. Kolb M. et al. Implementing Sustainability as the New Normal: Responsible Management Education - From a Private Business School's Perspective // The International Journal of Management Education. - 2017. - Vol. 15. - pp. 280-292.

7. The World University Rankings. World University Ranking 2019. Available: https://www.timeshighereducation.com/world-university-rankings/2019/worldranking\#!/page/0/length/25/sort_by/rank/sort_order/asc/cols/stats.

8. QS Quacquarelli Symonds Limited. QS World University Rankings 2019. Available: https://www.topuniversities.com/university-rankings/world-university-rankings/2019.

9. AACSB Home Page. Available: https://www.aacsb.edu/. Retrieved: 14.11.2018.

10.EFMD Quality Improvement System. EFMD Global Home Page. Available: https://efmdglobal.org/accreditations/business-schools/equis/. Retrieved: 14.11.2018.

11. Association of AMBAs Home Page. Available: https://www.mbaworld.com/. Retrieved: 14.11.2018. 